\title{
Sustainability in Historic Urban Environments: Effect of gentrification in the process of sustainable urban revitalization
}

\author{
Dr. Rokhsaneh Rahbarianyazd \\ Department of Architecture, Faculty of Architecture, Eastern Mediterranean University, Turkey \\ E mail: rokhsaneh.rahbarianyazd@gmail.com
}

\begin{tabular}{|l|}
\hline A R T I C L E I N F O: \\
\hline Article history: \\
Received 20 October 2016 \\
Received in revised form 27 \\
December 2016 \\
Accepted 2 January 2017 \\
Available online 2 January \\
2017 \\
\hline Keywords: \\
Revitalization; \\
Historic urban \\
environments; \\
Sustainability; \\
Gentrification. \\
\hline
\end{tabular}

This work is licensed under a Creative Commons Attribution NonCommercial - NoDerivs 4.0. "CC-BY-NC-ND"

\begin{abstract}
A B S T R A C T
Considering three-dimensional process of sustainability (physical-economical and social), the aim of conservation for making historic urban environment sustainable should be matched with these dimensions. Therefore, earlier conservation policies have progressed from a simple and restrictive concern with preservation to an increased concern for revitalization and enhancement. This means a physical revitalization may be short-lived and un-sustained. Within the process of revitalization, historic environments become the main locations of gentrification induced by urban revitalization which may involve social cost. Accordingly, this paper develops theoretical concepts on "sustainability in historic urban environment" with a particular emphasis on social issue in terms of gentrification. Also with the result derived from theoretical parts concludes that social changes through gentrification contribute to sustain the historic environments.
\end{abstract} CONTEMPORARY URBAN AFFAIRS (2017) 1(1), 1-9. https://doi.org/10.25034/1761.1(1)1-9

Copyright (C) 2017 Journal of Contemporary Urban Affairs. All rights reserved.

\section{Introduction}

The historic urban environment provides a tangible link with people's past and contributes to their sense of national, local and community identity and will provide the character and uniqueness that is an important matter to a positive sense of place. Additionally, it can bring additional assessment, not only as a cultural enhancement, but also as an economic stimulus, attract inner investment, play a dynamic part in

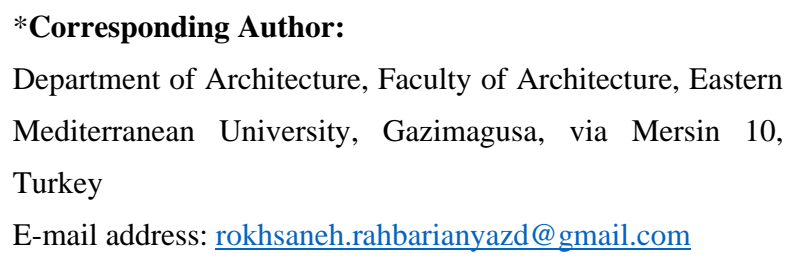


many industries such as tourist and helping communities to regenerate and support in the distribution of housing, community cohesion and education aims to support social development and "sustainable economic" of its communities (Department for Communities and Local Government, 2012; Veirier, 2008; Scottish Government, 2008). Recognizing the special needs of the historic urban environment, improvement and enabling of occasions for high-quality progress which embedded in those environments can assist to sustain the resource (Scottish Government, 2008).

Historic urban environments start with two essential qualities that implement in defining sense of belonging, social cohesion and a sense of place: a) first, the environmental capital that is meant by urban infrastructure and their buildings b) second the "socio-cultural values". Historic environments are stated in the urban grain, architecture, and the socio-economic organization of cities. Historic environments contain physical and immaterial cultural heritage, environmental matters, equity within and among age group (Rodwell, 2007). Historic areas and their surroundings should considered as irreplaceable universal heritage and in their totality as a coherent whole which include buildings, human activities and the spatial organization within its atmospheres. (UNESCO, 1976).

Along with the cities development and changing in socio-economic, socio-politic and socio cultural conditions, these environments fall into a kind of incompatibility between the capability of buildings and users' needs (Doratli, 2005). As a result, many people and activities, move out from areas in order to be close to the contemporary amenities. These problems contribute to the decrease in livability, vitality and sustainability of the "historic urban quarters" (Vehbi et al., 2009)

\footnotetext{
1 "Department of Culture, Media and Sport/Department of Transport Local Government and the Regions (2001) A
}

In the form of these threats, the idea is becoming prevalent that the solution to these tensions is the utilization and applicability of sustainability principles in historic urban environments (Rodwell, 2007; Strange, 1997; Pendlebury, 2009; Gunay et al., 2010). Stubbs, M. (2010) point out 'A Force for Our Future' (DCMS/DTLR, 2001)' was published in which the heritage sector was regarded as "something of a sleeping giant both in cultural and economic terms". A notion or vision was debut that heritage was an important component of a broader sustainable agenda. Thus, many historic urban quarters rather than being destroyed and redeveloped due to impacts of de-urbanization which was often the case in the 1950s and 1960s, is now being revitalized (Tiesdell et al., 1996). Recognizing and acting upon the full range of values inherent in historic environments is a core component of the challenge (Rodwell, 2007). In this background revitalization as a part of an unified 'conservation process' in the historical context which includes preservation and development (Veirier, 2008) is the best way to overcome various types of obsolescence and make conservation activity "sustainable" (Vehbi et al., 2009). Revitalization efforts need to operate within a sensitive context which acts as both a restriction and advantage. All urban areas undergo change, but these areas have to manage with change in their economic fortunes while changes in their physical landscapes is restricted and controlled in the interests of conservation (Tiesdell et al., 1996).

Accordingly, this paper tries to define the successful approach to apply the term sustainability in historic urban environment. Adopting sustainability as a code in management of historic quarters to ensure a balance among the requirement to keep the values of cultural heritage in historical environment, financial interests and sociocultural needs. Secondly, this paper will focus on

Force for Our Future, London, DCMS.” 
the social dimension of sustainability in the process of revitalization in historic quarters, which these days are the most important issue. Finally, a general conclusion will be presented to summarize all the arguments of the paper.

\section{Concept of sustainability and urban revitalization in historic urban environment}

The Brundtland Report provided definition of sustainable development as "a development that meets the needs of the present without compromising the ability of future generations to meet their own needs" (World Commission, 1987). While this meaning offers a comprehensive definition of sustainable development it has also been observed as being imprecise and vague (Stubbs, 2010; Ross et al., 1995). All the same the term "sustainable development" based on the requirement of the historic context might use in different ways (Rydin, 1997). The 1999 UK approach on "sustainable development" identifies four principal goals of sustainable development which are environmental protection, social progress, cautious use of resources and keep of stable and high levels of economic performance and growth (UK Government, 1999).

While Sustainable development has been for years appertain with the environment, after 1980s, it began to be in the schema of development procedure, inasmuch as environmental approach was short tactic to the new problems of changing political and socioeconomic conditions, sustainable development operated by social and economic issues as well. Accordingly securing the sustainable future of historic environment - physical, social and environmental - has become one of the core agendas of time (Rodwell, 2003; Gunay et al., 2010). From the other hand, when historic urban environments are considered in the goals of sustainability, it reveals an obligation to carry on the involvement of "cultural heritage" to present day via sensitive methods (Gunay, et al. 2010). Stubbs, (2010) notes the link among historic environment and sustainability is a comparatively new method, originated from the policy work and research undertaken since the mid-1990s. There is no wonder that the draft of "London Plan English Heritage" made the fact that "sustainability is an integral part of the protection of the historic environment. Revitalization provides the appropriate management tool for sustaining the built environment. Historic buildings are a reservoir of embodied energy while construction of new buildings is resource depleting" (English Heritage, 2002).

The view with regard to cultural heritage issues has been changed frequently, particularly since the 1960s. The notion of "a future for the past" in 70 s changed to the concept of "a past for future" in 80s and now the slogan "to make the past part of our future" has been created (Habibi, 2002). Therefore the concept of urban conservation/ revitalization has been changed since at least the 1960s and due to this issue, historic environments become the center of change and transformation demands which in some steps have given way to unexpected, rapid transformation process in all spheres of daily life (Rodwell, 2007; Gunay et al., 2010). While the roots of sustainability with urban revitalization are different, they share common ground. Revitalization and sustainability have equivalent meanings and are often used to slow the need to manage the world's properties: a) first, to secure long-term harmony between man and nature/built environment. and b) second, to achieve incessant improvement in the environment and quality of life for humans (Rodwell, 2007).

\subsection{Urban revitalization}

Although definition of revitalization is common in many scholars (Tiesdell et al., 1996; Bizzarro et al, 1996; Oc et al., 2007; Doratli, 2005) the appropriate one was introduced by Veirier (2008) in a manual book based on the work of UNESCO's Urban Development program: 
"Reaching a satisfactory balance between the laws of economic development, the needs and the rights of inhabitants and the value enhancement of the city as a public good. In the process of revitalization economic, heritage, sociocultural and environmental approaches do not clash; they are complementary and long-term success is in need of linking together of these approaches".

Within the scope of social and economic revitalization in historic environment, Tiesdell et al., (1996) and Doratli (2005) determined three strategic approaches in order to secure its success for long-term:

Functional restructuring: It can arise from changes in occupation in an area by introducing new uses or activities which is replacing the former ones.

Functional diversification: A more limited restructuring that brings in new uses able to support the quarter's existing economic base.

Functional regeneration: existing uses keep on, but activate more efficiently or profitably.

In this regard, A physical revitalization is also needed because it results in an absorbing, wellkept the physical public domain.

Doratli (2005) believes that in order to determine any type of strategic approaches in an environment an analysis of the physical, economic and social structure of the historic urban environment is needed:

(i) Identifying the values of the environment.

(ii) The level of obsolescence.

(iii) The dynamics of the place.

Though, regarding the process of sustainable urban revitalization, Vehbi et al., (2009) state that "along with mentioned analysis, the level of sustainability ${ }^{2}$ should also be determined. It means, the type and level of obsolescence, the types of values, the level of sustainability in

${ }^{2}$ The level of sustainability was identified through indicators of sustainability which were specific for historic urban quarters. (See Vehbi et al., 2009). historic urban environments, and development dynamics should be determined through analysis in the natural, built and socio-economic structures of the historic urban environment before signifying the strategic approach" (Figure 1).

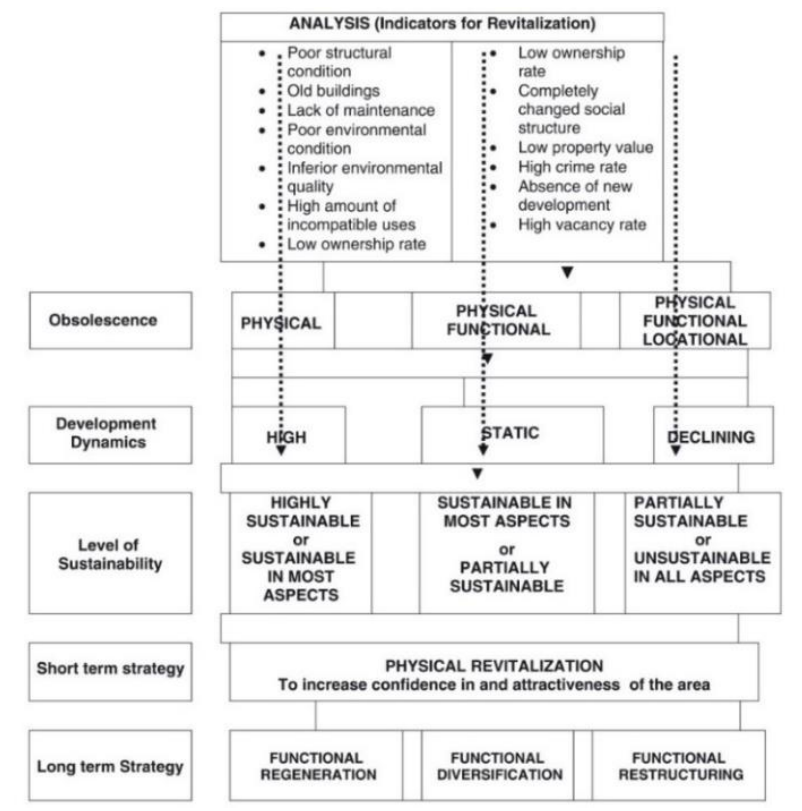

Figure 1: The most relevant strategic approach according to analysis and level of sustainability in revitalization process (Doratli, 2005; Oktay, 2009)

Much of the global debate about sustainability in historic environment has little relevance to revitalization if they are only thought of in terms of physical characteristic (Rodwell, 2007; Tiesdell et al., 1996) and in the long-run operations need to consider spatial, socio-cultural and financial responsibilities as key for sustainable strategies (Rodwell. 2007; Roald, 2000; Stubbs, 2010; Bizzarro and Nijkamp, 1996). It means only physical revitalization might be un-sustained, if the area fails to be responsive in terms of social and economic needs. It can realize that a thoughtful of environmental capacity as a whole should deliver adequate warning to enable an appropriate management and planning framework to set in place before problems 
become unmaintainable (Doak and Lynch, 1998).

\section{Sustainable urban revitalization through gentrification}

In this part, the study aimed to extract some social issue during the process of urban revitalization and will evaluate rather than these issues are inevitable to make the historic urban environment sustain or not?

While urban revitalization has been viewed as a part of a sustainable and integrated conservation process of the cultural, architectural properties by highlighting their economic and social capacities; however, they are being pushed of their social context and turned into an expression of the economic and political interests and gained new values within the framework of personal interests. As a result of these changes, urban revitalization is pushed backwards in some cities (Gulersoy et al., 2003; Gunay, et al., 2010) and was often beset with social difficulties such as expulsion of vulnerable groups and obliteration of existing social networks (Couch, 1990; Lee, 2003) in terms of gentrification.

The term "Gentrification" was used for the first time by Glass in the 1960s to clarify a "residential replacement" in London. "Gentrification" has been developed based on two different theories: a) socially deteriorating classes or the use of some parts of the city by emergent social classes and b) some art-oriented at the expenditure of other economically (Longa, $2011: 36)$. The first theory connects alteration to the people of one specific area, such as, the working-class of the central city, transforming into middle-class commercial or residential use which have been organized with an allied alteration in the built environment through investing in "fixed capital" (Zukin, 1987, p. 129; Atkinson, et al., 2005). According Tonkiss (2005) the second theory can be introduced based on technical concerns for the specific parts of the city by creative class strategies (such as people working in the fashion industry, artists, architects, and musicians) and make it viable and revitalized like SoHo in New York. This issue considers revisited and "avant-garde" form of "Gentrification" which act as added cultural explanation of "gentrification" (Ley 1994). The phenomenon of "Gentrification" as people based movement is also shared by Florida and Mellander with his "Creative Class". This type of revitalization process may create a new desirability to the areas and artists may progressively substitute by upper salary. The straightforward proposal is that urban creativity which is confined to a small area can alter tasks into areas which good-looking to higher income contexts (Zukin, 2010). Overall, both group's intention is to prevent environmental deterioration.

Manzi (2010) in the book Social Sustainability in Urban Areas developed "facilitating gentrification" as a theme that has emerged from research into sustaining mixed-income communities. In his book, He also stated that it is problematic to find firm evidences that workingclass groups are being intentionally excluded from new "mixed-income" community developments. A crucial aspect of a mixed community' agenda is the need to generate economic activity, in order that localities can become neighborhoods of choice rather than neighborhoods of last resort (Manzi, 2010). Overall, "economic segregation" signifies the most essential factor of whether mixed communities can work (Meen et al., 2005).

Keep all comments in mind, "the World Commission on Environment and Development report" (WCED, 1987) and UNESCO (2007) recommend that "social sustainability" look for to safeguard the environment through "economic growth" and the mitigation of poverty and improves the living conditions of all urban residents. Sustainable societies, although meet various needs of current and forthcoming occupants, are susceptible to their environment and chip in to a high quality of life. They are well planned, safe and comprehensive, built and run, 
and offer equivalent opportunity and good amenities for all (ODPM, 2006).

\section{Conclusion}

The study revealed that, parallel with the principles of sustainable development, the responses to historic environments have led to a new approach of urban conservation which involve social and economic aspects.

The aims of revitalization in historic urban environments are common with sustainability, which first has focused on efforts to make the economic development able to provide the finance necessary to preserve and improve the quarter through regeneration of the traditional activities of the locality or a restructuring of the quarter's economic base and second social interaction within the area.

Considering the literature, historic environments are the most vulnerable parts of cities in regards to its social sustainability. Although many scholars mentioned that the process of urban revitalization may undermine the social balance through displacement of the original population/ gentrification, here it may seem as a positive concern. Despite gentrification seems to be a negative outcome of urban revitalization, in some cases it is an unavoidable procedure to have a sustainable historic urban environment. If people understand the causes and aims of gentrification, its consequence turns out to be favorable. Because without underlying societies to economic revitalization in order to support core services, infrastructure and maintain, it is extremely doubtful such societies and environment will be sustainable. This doesn' $t$ mean the historic environment should gentrify and be a place for high income people, rather means the creative class who are often young people, with low income are interested to be in the historic urban environment. Figure 2 tries to show the historic environment as an interconnected ring with the three overlapping circles and cores of sustainability.

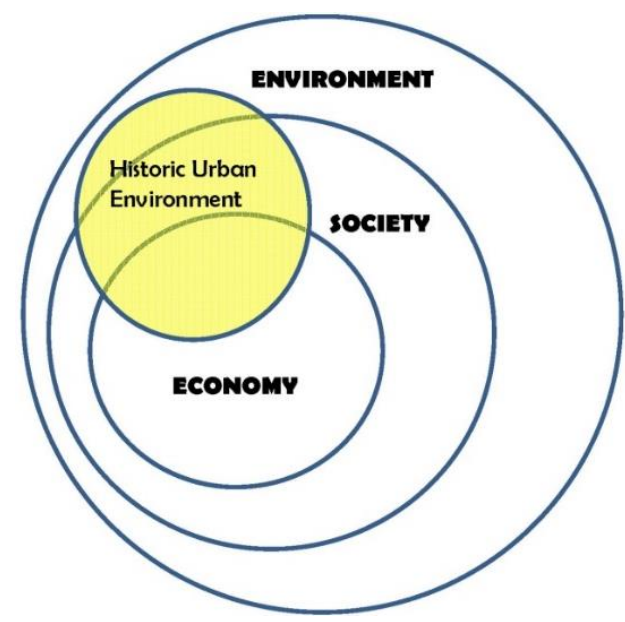

Figure 2. Location of historic environment in the overlapping Russian Doll model (Author, 2014).

Therefore, during the process of revitalization person who tends to be in the area should be aware of the environmental value and take the sensibility of the environment into consideration and make it sustain in terms of physical and economic through stability in incompatible/appropriate use and in the contextual situation.

This can be done with all communities, whether low class, middle or high, whether artists or none and they should involve in the process of urban conservation in search of a balance between economic, environmental, cultural and social constraints and governing the concept of social justice with a strategic planning. As Stubbs (2010) notes that increasing people's confidence and self-esteem is a vigorous component of "social inclusion" in such a kind of area. The broader concern for "conservation-led regeneration" is that harnessing historic buildings needs a strong idea of the needs of "local people". Overall, The following figure reveals different terms used in the process of historic urban revitalization. 


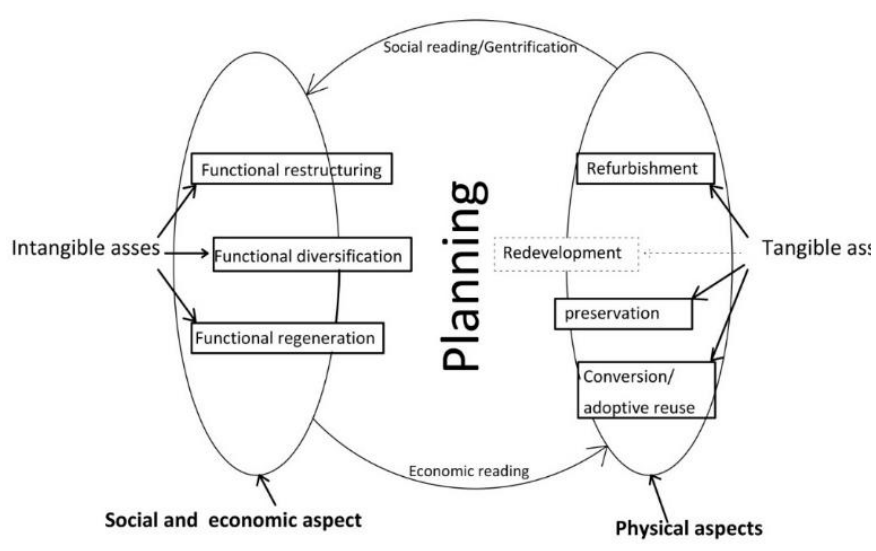

Figure 3. Classification of the different terms used in the process of historic urban revitalization considering with indicators of sustainability (Developed by Author, 2016).

Since unplanned urban growth problems threaten the life quality and sustaining of any environment, the need for planning approaches on total quality management is important. From the location of historic urban environments in figure 2 and classification of urban revitalization in figure 3 it can be understood planning interest in the historic urban environment covers statutory for preserving monumental and special structures in environmental part and nonstatutory designations to bring all the communities involve with its process of revitalization in social and economic parts.

\section{Acknowledgment}

This research did not receive any specific grant from funding agencies in the public, commercial, or non-for-profit sectors.

\section{References}

Abdi, M. and Mehdizadegan, N. (2008) Spatial Planning as an Approach to Achieve Sustainable Development in Historic Cities. World Academy of Science, Engineering and Technology. 2(1), 10-21.

Atkinson, R., \& Bridge, G. (2005) Gentrification in a global context, the new urban colonialism, London: Routledge.

Bizzarro, F. \& Nijkamp, P. (1996) Integrated conservation of cultural built heritage. In: P.S. Brandon, P.L. Lombardi, V. Bentivegna (eds)
Evaluation of the Built Environment for Sustainability, 451 471, E \& FN Spon: London.

Canada's historic places. (2007) Sustainable Development: Heritage Conservation Brief. APT Bulletin, 36 (4), 5-11.

Chan, R. (2011) Old Buildings, New Ideas: Historic Preservation and Creative Industry Development as Complementary Urban Revitalization Strategies. (Masters Thesis). University of Pennsylvania, Philadelphia, PA.

Colantonio, A and Dixon, T. (2010) Urban Regeneration and Social Sustainability: Best Practice from European Cities, Oxford:WileyBlackwell.

Couch, C. (1990) Urban renewal theory and practice. London: Macmillan Education Ltd.

Doratli, N. (2005) Revitalizing historic urban quarters: A model for determining the most relevant strategic approach, European Planning Studies, 13(5), 749-772.

Doak, J. and Lynch, J. (1998) Urban conservation areas and sustainable development: exploring the relationship. Working Papers in Land Management \& Development, (Report No. 10/98).

Department for Communities and Local Government. (June 2012) PPS5 Planning for the Historic Environment: Historic Environment Planning Practice Guide. Communities and Local Government Publications: Uk.

English Heritage. (2000) The Power of Place. The Future of the Historic Enviroment, London: English Heritage.

Florida, R. L. (2002) The Rise of the Creative Class: And how It's Transforming Work, Leisure, Community and Everyday Life. New York: Basic Books.

Gaeltacht, I. D. (2012) Shaping the Future: Case Studies in Adaptation and Reuse in Historic Urban Environments. Stationery Office Dublin: Ireland.

Gülersoy, N. Z. Eren, N. Özsoy, A. Tezer,A \& Yiğiter,R. (2009) Strategic quality planning in urban environment. Istanbul Technical University Faculty of Architecture 6 (1), 109125. 
Gunay, Z \& Gulersoy, N. Z. (2010) Sustainability of Historic Environment in the Neoliberal Age. International Society of City and Regional Planners. 46th ISCOCARP Congress 2010.

Gulersoy, N., Tezer, A., Yigiter, R., Koramaz, K. \& Gunay, Z. (2003) Istanbul Project - Istanbul Historic Peninsula Conservation Study Zeyrek, Suleymaniye and Yenikapı Historic Districts, Volume 1: Conservation of Cultural Assets in Turkey, Istanbul, UNESCO-World Heritage Center, ITU Faculty of Architecture, Istanbul, turkey :Urban and Environmental Planning and Research Center.

Habibi, M. (2002) Urban Regeneration. Tehran, Iran: Tehran University publication, pp.3-5.

Kasinitz, P. (1988) The Gentrification of 'Boerum Hill': Neighborhood Change and Conflict over Definitions. Qualitative Sociology, 11 (3), 163-82.

Landorf, C. (2011) Governance in historic urban environments: A theoretical review. International Journal of Heritage and Sustainable Development, 1 (1), 7-16.

Larsen, Gary L. (1994) Forests at UNCED: An Emerging Global Consensus Toward Sustainability. In Expanding Horizons of Forest Ecosystem $M$ anagement: Proceedings of the Third Habitat Futures Workshop, October 1992, Vernon, BC, edited by M. H. Huff, L. K. Norris, J. B. Nyberg, and N. L. Wilkin. Portland.

Lee, J. S. (2003) Enhancing sustainability in downtown by triple-value adding to urban redevelopment efforts: A case study of Seoul, Korea. Master Thesis. University of Washington.

Lees, L. (2003) Super-gentrification: The Case of Brooklyn Heights, New York City. Urban Studies, $\quad 40$ (12), 2487-2509. doi:10.1080/0042098032000136174

Ley, D. (1994). Gentrification and the politics of the new middle class. Environment and Planning D: Society and Space, 12(1), 53 - 74. doi:10.1068/d120053

Longa, R. D. (2011) 'Urban Models' in Urban Models and Public-Private Partnership (1 edition.), edited by Longa, R. D.; Springer Berlin Heidelberg pp.36-38.

Meen, G., Gibb, K., Goody, J., McGrath, T. and McKinnon, J. (2005) Economic Segregation in England: Causes, Consequences and Policy, JRF, London: The Policy Press

Manzi, T., Lucas, K., Jones, T. L., \& Allen, J. (2010). Social Sustainability in Urban Areas: Communities, Connectivity and the Urban Fabric. London; Washington, DC: Routledge.

Meen, G., Gibb, K., Goody, J., McGrath, T. and McKinnon, J. (2005) Economic Segregation in England: Causes, Consequences and Policy, The Policy Press/JRF, London.

National Board of Antiquities. (2006) Sustainable Historic Towns Urban heritage as an Asset of Development. Project Report. (Ed. Marianne Lehtimäki et al). First edition. Publisher: Sustainable Historic Towns: Finland.

Oc, T., Tiesdell, S. \& Heath, T. (2007) Design in historic environments, in: S. O. Gur (Ed.) Proceedings: Livenarch III: Contextualism In Architecture, 3rd International CongressLiveable Environments \& Architecture, July 57, Trabzon, Turkey, Vol II, pp. 343-367.

Office of the Deputy Prime Minister (ODPM). (2006) UK Presidency: EU Ministerial Informal on Sustainable Communities Policy Papers. London: ODPM press.

Pendlebury, J. (2009) Conservation in the Age of Consensus. London: Routledge.

Ross, A., Rowan-Robinson, J. \& Walton, W. (1995) Sustainable development in Scotland: the role of Scottish Natural Heritage. Land Use Policy, 12 (3), 237-52.

Roald H.J. (2000) Sustainable Historic Cities? A Baltic-Nordic Approach: Report on Urban Development and Cultural Values, Oslo: Akribe. Rodwell, D. (2002) From accolade to responsibility, London: Context. p. 30.

Rodwell, D. (2003) Sustainability and the holistic approach to the conservation of historic cities, Journal of Architectural Conservation, $1(3), 58-73$. 
Rodwell, D. (2007) Conservation and Sustainability in Historic Cities (1 edition.). Malden, Mass: Wiley-Blackwell.

Rydin, Y. (1997) Policy networks, local discourses and the implementation of sustainable development, in: S. Baker, D. Kousis, D. Richardson \& S. Young (Eds), The Politics of Sustainable Development, pp 152-74 (London, Routledge).

Stubbs, M. (2010) Heritage-sustainability: developing a methodology for the sustainable appraisal of the historic environment. Planning Practice and Research, 19(3), 285-305. doi:10.1080/0269745042000323229

Strange, I. (1997) Planning for change, conserving the past: towards sustainable development policy in historic cities. Cities. 14(4). 227-233.

Scottish Government, S. A. H. (2008, October 28) Scottish Planning Policy SPP 23 Planning and the Historic Environment. Publication. Retrieved June 19, 2014, from http://www.scotland.gov.uk/Publications/20 08/10/28135841/0

Tiesdell, S., Taner, O. \& Tim, H. (1996) Revitalizing Historic Urban Quarters. London: Architectural Press.

Tonkiss, F. (2005) Space, the city and social theory: Social relations and urban forms. Cambridge: Polity.

UNESCO. (1976) Recommendation concerning the Safeguarding and Contemporary Role of Historic Area. Retrieved from: http://www.icomos.org

UNESCO. (2007). UNESCO International Seminar: Balanced Urban Revitalization for Social Cohesion and Heritage Conservation: Tsinghua University, 21 to 23 January 2007. UNESCO.

UK Government (1994) Sustainable Development-The UK Strategy, London, HM Stationery Office.

UK Government (1999) A Better Quality of Life. A Strategy for Sustainable Development for the United Kingdom, London, HM Stationery Office.
United Nations Conference on Human Settlements, (1996) Habitat II, World Assembly of Cities and Local Authorities, May 30-31 1996, Istanbul.

Veirier, L. (2008) Historic districts for all, a social and human approach for sustainable revitalization. United Nations Educational, Scientific and Cultural Organization (UNESCO). Retrieved June 3, 2014, from: http://otp.unesco-ci.org/trainingresource/heritage-preservation/historicdistricts-all-social-and-human-approachsustainable

Vehbi, B. O., \& Hoşkara, Ş. Ö. (2009) A Model for Measuring the Sustainability Level of Historic Urban Quarters. European Planning Studies, 17(5), 715-739. Doi: $10.1080 / 09654310902778201$

WCED. (1987) Our Common Future, Oxford, Oxford University Press.

Zukin, S. (1987) Gentrification: Culture and Capital in the Urban Core. Annual Review of Sociology, 13, 129-147.

Zukin, S. (2010) Naked city: the death and life of authentic urban places. Oxford; New York: Oxford University Press. 